\title{
Characterization of body biometrics during growth of elite Santa Ines sheep
}

\author{
Milton Rezende Teixeira Neto ${ }^{1}$, Jurandir Ferreira da $\mathrm{Cruz}^{2}$, Carlos Henrique Mendes \\ Malhado $^{3}$, Paulo Luiz Souza Carneiro ${ }^{3}$, Rita de Cássia Santos Nunes ${ }^{2}$, Luiz Miranda Souza ${ }^{4}$, \\ Luiz Eduardo Barreto de Souza ${ }^{1}$
}

\footnotetext{
1 Pós-Graduação em Zootecnia, UESB - Itapetinga, BA.

2 Departamento de Fitotecnia e Zootecnia, UESB - Vitória da Conquista, BA.

${ }^{3}$ Departamento de Ciências Biológicas, UESB - Jequié, BA.

${ }^{4}$ Secretaria da Agricultura, Irrigação e Reforma Agrária - BA.
}

\begin{abstract}
The objective of this study was to characterize body biometrics of Santa Ines sheep during growth. Data from 4,038 animals, males and females, with ages from four to 36 months, from different herds participating in the National Agricultural Fair in Bahia from 2003 to 2008 were used. The characteristics evaluated were: body weight, average daily gain, body length, thoracic circumference, anterior height and posterior height. The mean values found were compared by the Student-NewmanKeuls test. All characteristics studied showed gradual change with aging, and it is worth-noting that age had positive effect on body weight, body length, thoracic circumference, anterior height and posterior height and negative effect on average daily gain Average daily gain was reduced by $68.5 \%$ from four to 36 months of age, while the mean improvements observed in both sexes in this age range, for body weight, body length, thoracic circumference, anterior height and posterior height were $137.8 \%, 23.5 \%$, $43.2 \%, 19.3 \%$ and $19.6 \%$, respectively. However, the increments for body weight, body length and thoracic circumference were higher until 12 months of age, when an increase of $72.7 \%, 14.6 \%$ and $24.8 \%$ in their respective characteristics was verified. For anterior height and posterior height, the greatest increase occurred up to eight months of age with improvement of $8.4 \%$ for both measures. Santa Ines sheep have different growth rates for body measurements; whereas growth in posterior height stabilizes earlier, the thoracic circumference, along with body weight, remains growing for longer time.
\end{abstract}

Key Words: average daily gain, body development, body measurements, body weight

\section{Introduction}

The dynamics of farming systems coupled with market demands have led to the continuous search for the optimal size of the animal. In this sense, it ought to be emphasized that profitability should guide this quest, once body weight and, consequently, the cost of maintenance and production are directly influenced by the size of the animal (Costa Júnior et al., 2006).

The Santa Ines breed has proven to be an excellent alternative to increase the production of sheep meat in different farming systems due to its good reproductive efficiency and growth rate (Sousa et al., 2003).

Sousa \& Morais (2000) remark that although larger body can demand a higher nutritional requirement and compromise reproductive efficiency, Santa Ines breeders prefer larger adult animals.

Body measurements, such as thoracic circumference, body weight and body length have been used in the definition of adult size, nutritional requirements and physiological maturity of the animals (Rocha et al., 2003). These measurements provide important information about the physical development according to sex and category, allowing the establishment of the relation between conformation and functionality of the animal (Araújo Filho et al., 2007).

The study of the development of body measurements in view of Santa Ines sheep age can contribute to a better understanding of body growth in this breed and thus, of its potential for meat production. In this context, this study aimed to characterize the body biometrics during growth of elite Santa Ines sheep.

\section{Material and Methods}

Data from body measurements of 4,038 animals of the Santa Ines breed, males and females, with ages between four and 36 months from different regions of Brazil, which participated in the National Agricultural Fair in Bahia State (FENAGRO), in the period from 2003 to 2008 were used.

The animals of both genders were divided into eight age ranges (Table 1). The characteristics evaluated were: body weight $(\mathrm{kg})$, average daily gain ( $\mathrm{g} /$ day), body length $(\mathrm{cm})$, thoracic circumference $(\mathrm{cm})$, anterior height $(\mathrm{cm})$ and posterior height $(\mathrm{cm})$. 
Table 1 - Distribution of animals by age intervals and gender

\begin{tabular}{|c|c|c|c|}
\hline Age interval & Age (months) & Gender & Number of animals \\
\hline \multirow[t]{2}{*}{1} & \multirow[t]{2}{*}{$4-7$} & Male & 444 \\
\hline & & Female & 839 \\
\hline \multirow[t]{2}{*}{2} & \multirow[t]{2}{*}{$8-11$} & Male & 359 \\
\hline & & Female & 717 \\
\hline \multirow[t]{2}{*}{3} & \multirow[t]{2}{*}{$12-15$} & Male & 174 \\
\hline & & Female & 383 \\
\hline \multirow[t]{2}{*}{4} & \multirow[t]{2}{*}{$16-19$} & Male & 193 \\
\hline & & Female & 387 \\
\hline \multirow[t]{2}{*}{5} & \multirow{2}{*}{$20-23$} & Male & 82 \\
\hline & & Female & 131 \\
\hline \multirow[t]{2}{*}{6} & \multirow[t]{2}{*}{$24-27$} & Male & 62 \\
\hline & & Female & 91 \\
\hline \multirow[t]{2}{*}{7} & \multirow[t]{2}{*}{$28-31$} & Male & 40 \\
\hline & & Female & 58 \\
\hline \multirow[t]{2}{*}{8} & \multirow[t]{2}{*}{$32-36$} & Male & 30 \\
\hline & & Female & 48 \\
\hline
\end{tabular}

Animals were weighed on a digital scale suitable for small ruminants and the biometric measurements (body weight, thoracic circumference, anterior and posterior heights) were performed with the aid of tape measure, as suggested by Searle et al. (1989).

The measurement of body length was made by measuring the distance between the cervicothoracic joint and the base of the tail in the first intercoccygeal joint, with the animal kept in the correct vertical position. The anterior height was measured from the highest point of the interscapular region to the ground; posterior height was measured from the sacral tuberosity of the ilium to the ground. The thoracic circumference was measured around the thorax, taking the withers and the armpits as bases. Average daily gain was calculated as the difference between body weight $(\mathrm{kg})$ at the time of measurement and birth, divided by the number of days in the period between the two weighings.

The statistical model considered age and sex as fixed effect, according to the equation:

$\mathrm{Y}_{\mathrm{ijk}}=\mu+\mathrm{id}_{\mathrm{i}}+\mathrm{sex}_{\mathrm{j}}+(\mathrm{id} * \mathrm{sex})_{\mathrm{ij}}+\mathrm{e}_{\mathrm{ijk}}$

where $Y_{i j k}=$ response observed for animal age $\mathrm{i}$ and sex $\mathrm{j}$; $\mu=$ overall mean; $i_{i}=$ age class $i(i=1$ to 8$) ;$ sex $_{j}=$ effect of $\operatorname{sexj}$ (male or female); $\left(\mathrm{id}^{*} \mathrm{sex}\right)_{\mathrm{ij}}=$ effect of the interaction of age and sex; and $\mathrm{e}_{\mathrm{ijk}}=$ random error associated with each observation with NID distribution $\left(0, \sigma^{2}\right)$.

Data were analyzed through the least squares method using the GLM procedure of SAS (Statistical Analysis System, version 6$)$. The means ( \pm standard deviation) were compared by Student-Newman-Keuls $(\mathrm{P}<0.05)$. Equations of the quadratic model were fitted using NLIN procedure (Statistical Analysis System, version 6).

\section{Results and Discussion}

The interaction of age vs. sex was significant $(\mathrm{P}<0.05)$ for body weight (BW), thoracic circumference, anterior and posterior heights, which did not occur with average daily gain $(\mathrm{ADG})(\mathrm{P}>0.05)($ Table 2$)$. All characteristics showed

Table 2 - Mean values ( \pm standard deviation) of body weight $(\mathrm{kg})$, average daily gain (g/day), body length (cm), thoracic circumference $(\mathrm{cm})$, anterior height $(\mathrm{cm})$ and posterior height $(\mathrm{cm})$ of Santa Ines sheep at different ages

\begin{tabular}{|c|c|c|c|c|c|c|}
\hline \multirow[t]{2}{*}{ Age (months) } & \multicolumn{2}{|c|}{ Body weight (kg) } & \multicolumn{2}{|c|}{ Body length (cm) } & \multicolumn{2}{|c|}{ Anterior height $(\mathrm{cm})$} \\
\hline & Male & Female & Male & Female & Male & Female \\
\hline $4-7$ & $49.6 \pm 7.9 \mathrm{Da}$ & $41.7 \pm 6.0 \mathrm{~Eb}$ & $72.6 \pm 4.9 \mathrm{Ca}$ & $68.2 \pm 4.1 \mathrm{Db}$ & $73.1 \pm 3.6 \mathrm{Ca}$ & $68.6 \pm 3.5 \mathrm{~Eb}$ \\
\hline $8-11$ & $71.4 \pm 10.6 \mathrm{Ca}$ & $56.9 \pm 8.5 \mathrm{Db}$ & $80.5 \pm 5.3 \mathrm{Ba}$ & $74.3 \pm 5.0 \mathrm{Cb}$ & $79.5 \pm 4.2 \mathrm{Ba}$ & $74.1 \pm 3.5 \mathrm{Db}$ \\
\hline $12-15$ & $90.0 \pm 14.5 \mathrm{Ba}$ & $68.3 \pm 10.0 \mathrm{Cb}$ & $83.4 \pm 4.9 \mathrm{Aa}$ & $78.0 \pm 5.4 \mathrm{Bb}$ & $80.6 \pm 2.9 \mathrm{Ba}$ & $75.9 \pm 3.7 \mathrm{Cb}$ \\
\hline $16-19$ & $94.3 \pm 11.1 \mathrm{Ba}$ & $74.5 \pm 13.8 \mathrm{Bb}$ & $85.3 \pm 4.4 \mathrm{Aa}$ & $78.8 \pm 5.1 \mathrm{ABb}$ & $82.9 \pm 3.7 \mathrm{Aa}$ & $77.1 \pm 3.5 \mathrm{BCb}$ \\
\hline $20-23$ & $110.0 \pm 14.9 \mathrm{Aa}$ & $87.7 \pm 13.2 \mathrm{Ab}$ & $86.9 \pm 6.3 \mathrm{Aa}$ & $80.1 \pm 6.4 \mathrm{ABb}$ & $83.4 \pm 7.8 \mathrm{Aa}$ & $78.8 \pm 3.6 \mathrm{ABb}$ \\
\hline $24-27$ & $117.5 \pm 10.7 \mathrm{Aa}$ & $87.7 \pm 10.1 \mathrm{Ab}$ & $87.5 \pm 3.4 \mathrm{Aa}$ & $82.7 \pm 4.8 \mathrm{Ab}$ & $85.5 \pm 3.6 \mathrm{Aa}$ & $79.6 \pm 5.2 \mathrm{ABb}$ \\
\hline $28-31$ & $120.2 \pm 13.8 \mathrm{Aa}$ & $90.6 \pm 12.6 \mathrm{Ab}$ & $89.8 \pm 5.3 \mathrm{Aa}$ & $83.1 \pm 4.1 \mathrm{Ab}$ & $86.2 \pm 3.3 \mathrm{Aa}$ & $79.9 \pm 3.1 \mathrm{ABb}$ \\
\hline $32-36$ & $123.9 \pm 10.5 \mathrm{Aa}$ & $94.2 \pm 13.7 \mathrm{Ab}$ & $90.1 \pm 5.1 \mathrm{Aa}$ & $83.8 \pm 5.6 \mathrm{Ab}$ & $88.1 \pm 3.9 \mathrm{Aa}$ & $80.9 \pm 4.1 \mathrm{ABb}$ \\
\hline \multirow[t]{3}{*}{ Coefficient of variation } & 0.1634 & 0.1726 & 0.0669 & 0.0670 & 0.0529 & 0.0501 \\
\hline & \multicolumn{2}{|c|}{ Average daily gain (g/day) } & \multicolumn{2}{|c|}{ Thoracic circumference $(\mathrm{cm})$} & \multicolumn{2}{|c|}{ Posterior height $(\mathrm{cm})$} \\
\hline & Male & Female & Male & Female & Male & Female \\
\hline $4-7$ & $354.4 \pm 66.7 \mathrm{Aa}$ & $296.0 \pm 39.4 \mathrm{Ab}$ & $84.5 \pm 6.5 \mathrm{Da}$ & $81.8 \pm 5.0 \mathrm{~Eb}$ & $73.4 \pm 3.5 \mathrm{Ca}$ & $68.7 \pm 3.2 \mathrm{~Eb}$ \\
\hline $8-11$ & $275.1 \pm 41.1 \mathrm{Ba}$ & $218.8 \pm 34.8 \mathrm{Bb}$ & $97.6 \pm 6.2 \mathrm{Ca}$ & $92.9 \pm 6.2 \mathrm{Db}$ & $79.7 \pm 4.2 \mathrm{Ba}$ & $74.3 \pm 3.5 \mathrm{Db}$ \\
\hline $12-15$ & $235.8 \pm 37.9 \mathrm{Ca}$ & $179.6 \pm 27.4 \mathrm{Cb}$ & $106.5 \pm 6.7 \mathrm{Ba}$ & $101.1 \pm 8.1 \mathrm{Cb}$ & $83.3 \pm 3.9 \mathrm{Aa}$ & $76.6 \pm 3.8 \mathrm{Cb}$ \\
\hline $16-19$ & $185.1 \pm 42.5 \mathrm{Da}$ & $146.6 \pm 28.3 \mathrm{Db}$ & $108.7 \pm 8.7 \mathrm{Ba}$ & $103.8 \pm 9.0 \mathrm{Bb}$ & $83.4 \pm 3.6 \mathrm{Aa}$ & $77.3 \pm 3.5 \mathrm{BCb}$ \\
\hline $20-23$ & $174.2 \pm 23.3 \mathrm{Da}$ & $138.5 \pm 21.3 \mathrm{Db}$ & $117.0 \pm 6.3 \mathrm{Aa}$ & $110.4 \pm 10.9 \mathrm{Ab}$ & $84.2 \pm 4.3 \mathrm{Aa}$ & $78.8 \pm 3.8 \mathrm{ABb}$ \\
\hline $24-27$ & $156.1 \pm 14.1 \mathrm{DEa}$ & $116.3 \pm 13.5 \mathrm{~Eb}$ & $120.4 \pm 7.2 \mathrm{Aa}$ & $111.4 \pm 12.7 \mathrm{Ab}$ & $84.6 \pm 3.3 \mathrm{Aa}$ & $79.8 \pm 4.2 \mathrm{ABb}$ \\
\hline $28-31$ & $136.7 \pm 15.8 \mathrm{Ea}$ & $102.7 \pm 14.9 \mathrm{~Eb}$ & $123.2 \pm 8.3 \mathrm{Aa}$ & $112.2 \pm 8.3 \mathrm{Ab}$ & $85.8 \pm 2.7 \mathrm{Aa}$ & $80.1 \pm 3.0 \mathrm{ABb}$ \\
\hline $32-36$ & $119.1 \pm 10.5 \mathrm{Ea}$ & $87.0 \pm 14.1 \mathrm{~Eb}$ & $124.1 \pm 6.3 \mathrm{Aa}$ & $114.3 \pm 9.4 \mathrm{Ab}$ & $88.4 \pm 3.9 \mathrm{Aa}$ & $81.6 \pm 4.0 \mathrm{Ab}$ \\
\hline Coefficient of variation & 0.1744 & 0.1817 & 0.0715 & 0.0789 & 0.0490 & 0.0493 \\
\hline
\end{tabular}

Means followed by different letters - uppercase in columns and lowercase in rows - differ $(\mathrm{P}<0.05)$ by SNK test. 
gradual change with aging; age showed positive effect on body weight, thoracic circumference, anterior and posterior heights and negative on average daily gain $(\mathrm{P}<0.05)$. The highest variation coefficients were observed for BW and ADG indicating that, among the characteristics evaluated, these are the more likely to suffer influence from environmental effects. Body measurements, however, showed values below 0.08 , reflecting the small influence of effects not considered in the model (Table 2). These results were similar to those obtained by Costa Júnior et al. (2006) with Santa Ines sheep.

Although body development occurred visually harmonious with advancing age, changes in traits occurred differently. While BW, in both sexes, underwent an average increase of $63.40 \mathrm{~kg}(138.9 \%)$ at the age range between four and 36 months, body length, thoracic circumference, anterior and posterior heights increases, at the same age range, were of $16.54 \mathrm{~cm}(23.5 \%), 36.02 \mathrm{~cm}(43.3 \%), 13.69 \mathrm{~cm}$ $(19.3 \%)$ and $13.93 \mathrm{~cm}(19.6 \%)$ (Table 3$)$.

Similarly to what was observed in the present study, Mehta et al. (1995), studying Malpura sheep, found that in both sexes BW, body length, thoracic circumference and anterior height had an increase of $25.0 \mathrm{~kg}, 20.9 \mathrm{~cm}, 26.2 \mathrm{~cm}$ and $18.4 \mathrm{~cm}$, corresponding to $153.5 \%, 35.4 \%, 35.0 \%$ and $28.3 \%$ increase in the age between three and 36 months, respectively. The sharp increase of $\mathrm{BW}$, also observed in the present study, resulted from the joint action of body length, thoracic circumference, anterior and posterior heights increases.

With regard to $\mathrm{BW}$, the values obtained for males aged $4-7,8-11$ and $12-15$ months were $40.1 \%, 57.7 \%$ and $72.7 \%$ of the weight of animals aged 32-36 months, respectively. While for females, BW at ages 4-7, 8-11 and 12-15 months corresponded to $44.2 \%, 60.3 \%$ and $72.5 \%$ of the weight of animals at 32-36 months, in same order.

$\mathrm{BW}$ increase was more intense at the age of four to 23 months, and the stabilization of this traits occurred at 28.7 months of age for females and at 32.6 months old for males, when they had $92.72 \mathrm{~kg}$ and $124.63 \mathrm{~kg}$, respectively (Figure 1).

Similarly to what was observed in the present study, Sahana et al. (2004) observed the largest increases for BW, from birth to 24 months of age, while studying Jalauni sheep. At this age, the weight values of $25.0 \mathrm{~kg}$ and $20.9 \mathrm{~kg}$, accounted for $70.4 \%$ and $76.8 \%$ of adult BW for males and females, respectively. In the present study, Santa Ines sheep (males and females) reached more than $70 \%$ of adult BW at the age of 12-15 months, showing a greater precocity in comparison with the Jalauni sheep.

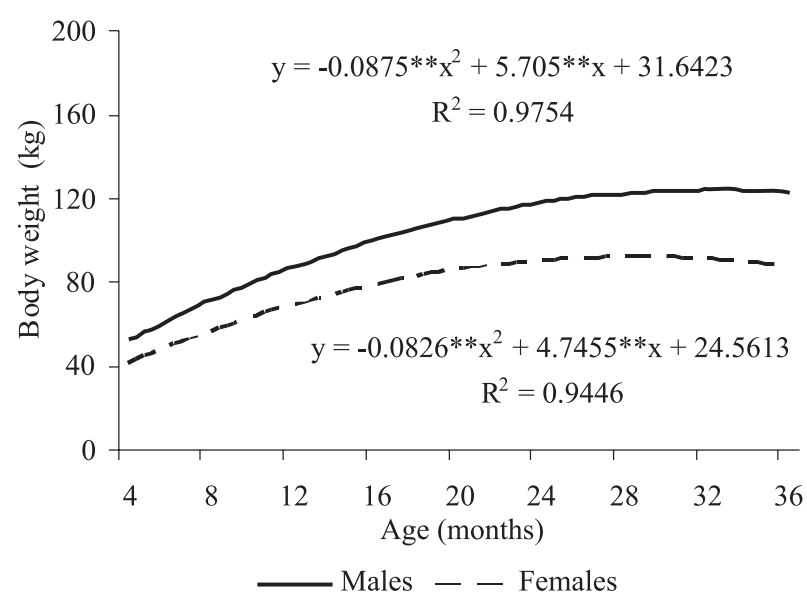

Figure 1 - Body weight of Santa Ines sheep with ages between four and 36 months; ** significant at $1 \%$ probability $(\mathrm{P}<0.01)$.

Table 3 - Increases, by age range (\%), of body weight, average daily gain, body length, thoracic circumference, anterior height and posterior height of Santa Ines sheep, from 2003 to 2008

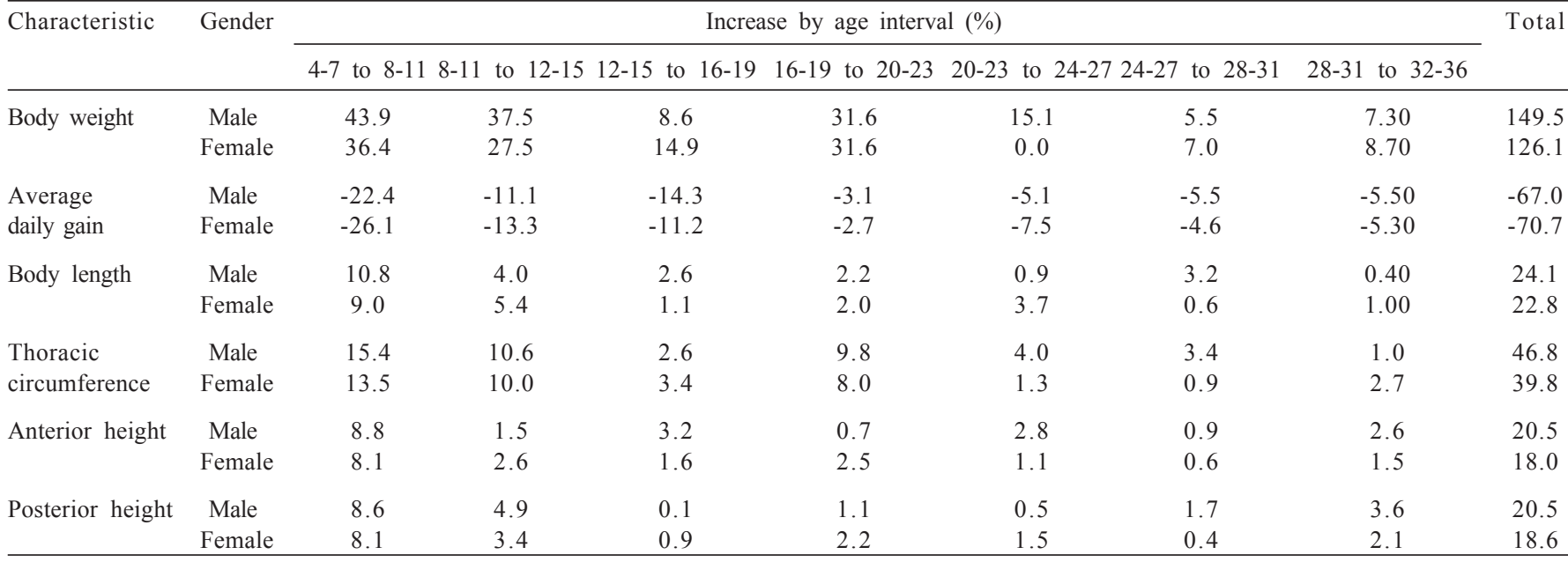


Regarding the influence of sex on $\mathrm{BW}$, it was found that males were heavier, on average, $21.93 \mathrm{~kg}(22.6 \%)$, and this superiority was most evident at the age between 24 and 36 months (24.7\%). In previous study with Santa Ines sheep, Quesada et al. (2002) found that at seven months of age males were $1.30 \mathrm{~kg}(4.5 \%)$ heavier than females.

The superiority of the males BW is probably the result of the activity of androgen hormones, which enable better use of nitrogen in protein synthesis and, therefore, in growth and muscle development (Pereira et al., 2000).

In both sexes, there was a progressive reduction of the ADG with advancing age, and this reduction was marked up to 19 months (Figure 2). However, high values of ADG $(>200 \mathrm{~g} /$ day) were found for males and females, up to 10 and 15 months of age, respectively, demonstrating the high potential of the Santa Ines sheep for meat production.

Average daily gain values found for males at 36 months of age showed a reduction of $66.4 \%, 49.5 \%$ and $23.7 \%$ in relation to those verified at the ages of 4-7, 12-15 and 24-27 months, respectively, whereas for females, this reduction was $70.6 \%, 51.6 \%$ and $25.2 \%$, in the same order. Similarly to what was observed in the present study, Sarmento et al. (2006), working with Santa Ines lambs, observed gradual reduction of ADG with advancing age, declining from $170 \mathrm{~g} /$ day to less than $30 \mathrm{~g} /$ day from the $2^{\text {nd }}$ to the $6^{\text {th }}$ months of age, corresponding to a reduction of $80.4 \%$.

The intensity of the reduction of ADG from four to 36 months of age was lower in males, and the value of ADG at 36 months accounted for $32.8 \%$ and $26.8 \%$ of that seen at four months, in males and females, respectively.

In a study with Santa Ines sheep in confinement, Furusho-Garcia et al. (2004) found that males and females, up to eight months of age, presented weight gain of

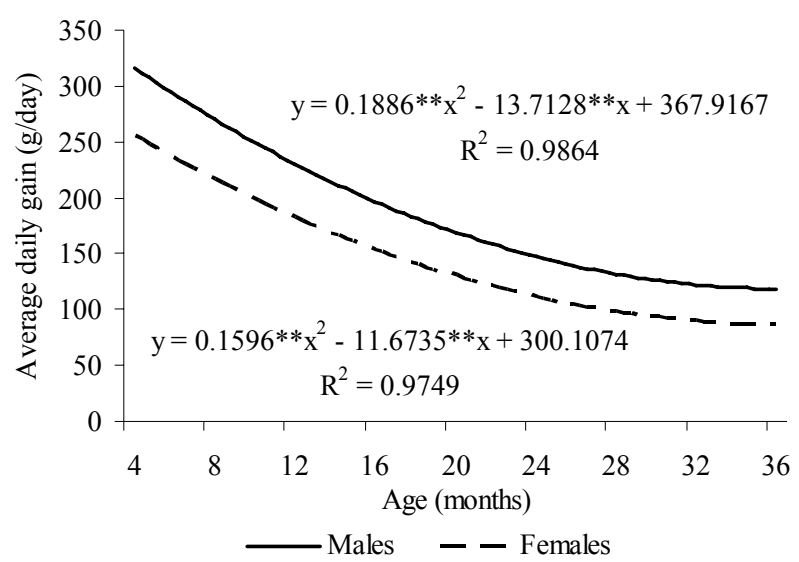

Figure 2 - Average daily gain of Santa Ines sheep with ages between four and 36 months; ** significant at $1 \%$ probability $(\mathrm{P}<0.01)$.
$216 \mathrm{~g} /$ day and $157 \mathrm{~g} /$ day, respectively. These findings were lower than those seen in animals of the same age in the present study. This significant difference can be explained by the genetic superiority of the animals in this present study, since this is an elite group of the race.

Average daily gain is a strategic variable to assess the strength of the growth of the animal. The selection for individuals with higher ADG at younger ages could substantially contribute to high production rates. According to Zundt et al. (2006) knowledge of the age in which the highest growth rate occurs enables the definition of the most appropriate age for slaughter, thus avoiding high fat deposition in carcass. Landim et al. (2007), evaluating the slaughter weight of Santa Ines sheep raised under semiintensive breeding system found ideal slaughter weight of $27.2 \mathrm{~kg}$.

The gender showed influence on ADG, and males were superior to females in all ages $(\mathrm{P}<0.05)$. In absolute terms, this superiority was more pronounced at ages 4 to 15 months, when males gained an average of $57 \mathrm{~g}$ /day higher than females.

With regard to body length, it was found that males were, on average, $6.9 \%$ superior to females, and this superiority was relatively constant, when it ranged between $4.42 \mathrm{~cm}(6.0 \%)$ and $6.75 \mathrm{~cm}(7.76 \%)$. These results corroborate the findings of Araujo et al. (1996) who, also evaluating Santa Ines sheep, found that up to 11 months of age males body length was $5.1 \mathrm{~cm}(9.4 \%)$ greater than that of females.

The increase in body length occurred more significantly from four to 15 months of age. The maximum values reached for this trait were verified at 27.3 months for males and 25.7 months for females, when they presented $91.17 \mathrm{~cm}$ and $83.24 \mathrm{~cm}$, respectively (Figure 3 ).

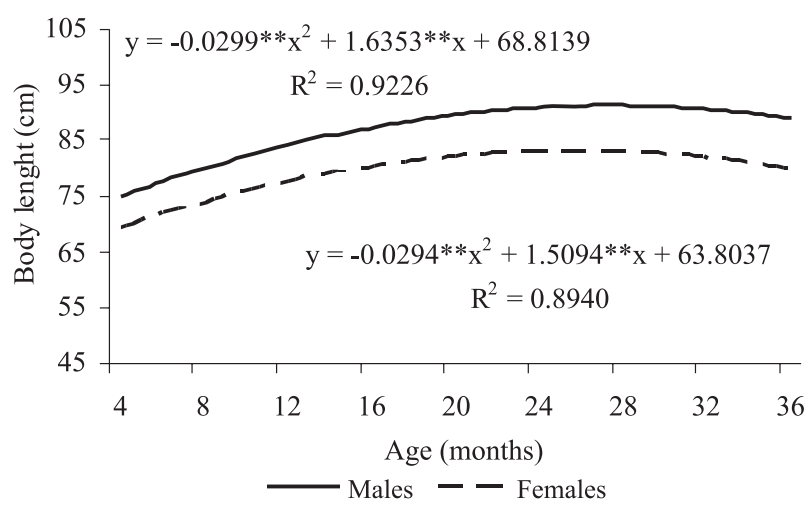

Figure 3 - Body length of Santa Ines sheep with ages between four and 36 months; ** significant at $1 \%$ probability $(\mathrm{P}<0.01)$. 
Males aged 4-7, 8-11 and 12-15 months presented body length of $80.6 \%, 89.3 \%$ and $92.6 \%$ of the body length at 36 months, respectively. For females of the same ages these values corresponded to $81.4 \%, 88.7 \%$ and $93.1 \%$ of the body length at 36 months.

Similarly to what was observed in the present study, Sahana et al. (2004), studying Jalauni sheep, observed the largest increases for body length from birth to 24 months of age. At this age, values found for males and females $(65.3 \mathrm{~cm}$ and $63.5 \mathrm{~cm})$ corresponded to $91.3 \%$ and $99.5 \%$ of body length of animals of ages 32-36 months, respectively. In the present study, Santa Ines sheep (male and female) reached more than $90 \%$ of body length of animals of ages 32-36 months, at the age of 12-15 months.

On the other hand, regardless of the gender, the highest increases occurred in younger age, confirming the findings of Mehta et al. (1995), who, working with Malpura sheep, observed higher body length increases, in both sexes, from birth to nine months of age, when the observed increase was $28.7 \mathrm{~cm}(52.3 \%)$.

Concerning thoracic circumference, it was found that males were superior to females in all ages, and this superiority was more evident $(10.4 \mathrm{~cm})$ between the ages of 28 and 36 months. These results are consistent with the findings of Costa Júnior et al. (2006), who also working with Santa Ines sheep found that males thoracic circumference were higher than females thoracic circumference in all categories evaluated, with observed values for males and females of $91.7 \mathrm{~cm}$ and $87.8 \mathrm{~cm}$ for young animals, and $117.0 \mathrm{~cm}$ and $107.5 \mathrm{~cm}$ in adults, respectively.

Thoracic circumference values obtained for males aged $12-15,20-23$ and $28-31$ months were $85.8 \%, 94.3 \%$ and $99.3 \%$ of the thoracic circumference at 36 months,

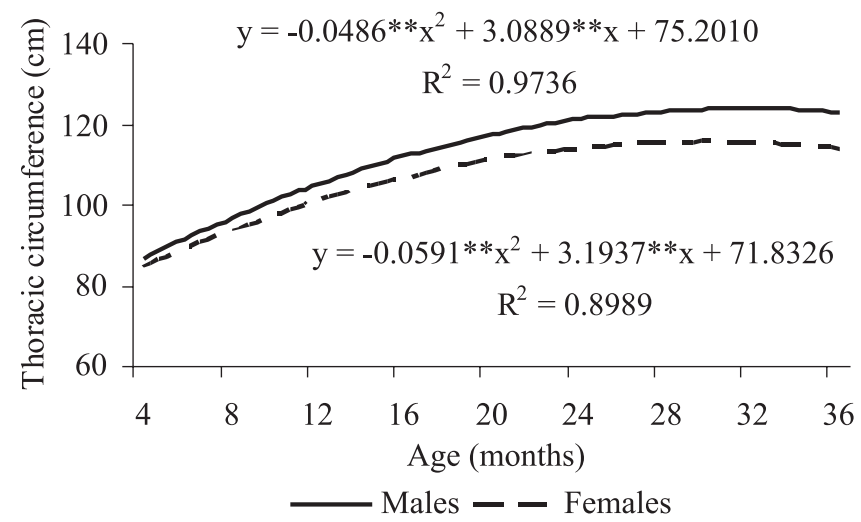

Figure 4 - Thoracic circumference of Santa Ines sheep with ages between four and 36 months; $* *$ significant at $1 \%$ probability $(\mathrm{P}<0.01)$. respectively, while for females, values were $88.4 \%, 96.5 \%$ and $98.1 \%$ compared with that same age.

The advance of thoracic circumference occurred more significantly in the age from four to 23 months, and this trait stabilized the growth at 31.8 and 27.0 months in males and females, which presented $124.28 \mathrm{~cm}$ and $114.97 \mathrm{~cm}$, respectively (Figure 4).

Musa et al. (2006), working with naturalized sheep of West Africa, observed that thoracic circumference increase in both sexes was more significant until 12 months of age. Similarly, Dixit et al. (2005), evaluating the Indian Bushair Rampur sheep, found a simultaneous deceleration of thoracic circumference in both sexes.

As for anterior height, it was found that males were on average $5.5 \mathrm{~cm}$ higher than females, and this superiority was more pronounced as the animals became older. These results are consistent with the findings of Araujo et al. (1996) who, also studying Santa Ines sheep, found that males up to 11 months of age showed anterior height $3.8 \mathrm{~cm}$ higher than females.

Anterior height increase was more expressive from four to 19 months of age. The maximum values reached for this feature were checked at ages 31.5 months for males and 25.9 months for females, when they presented $88.32 \mathrm{~cm}$ and $80.24 \mathrm{~cm}$, respectively (Figure 5).

Anterior height values for males of ages 4-7, 12-15 and 20-23 months amounted to $82.9 \%, 91.4 \%$ and $94.7 \%$ of anterior height at 36 months aged, respectively, while for females, anterior height values found in the same age group were equivalent to $84.7 \%, 93.8 \%$ and $97.4 \%$ of anterior height at 36 months of age, in the same order.

Increases in anterior height observed for males between the first age range (4-7 months) and the ranges of 8-11, 12-15 and $16-19$ were $6.4 \mathrm{~cm}, 7.5 \mathrm{~cm}$ and $9.8 \mathrm{~cm}$, corresponding to

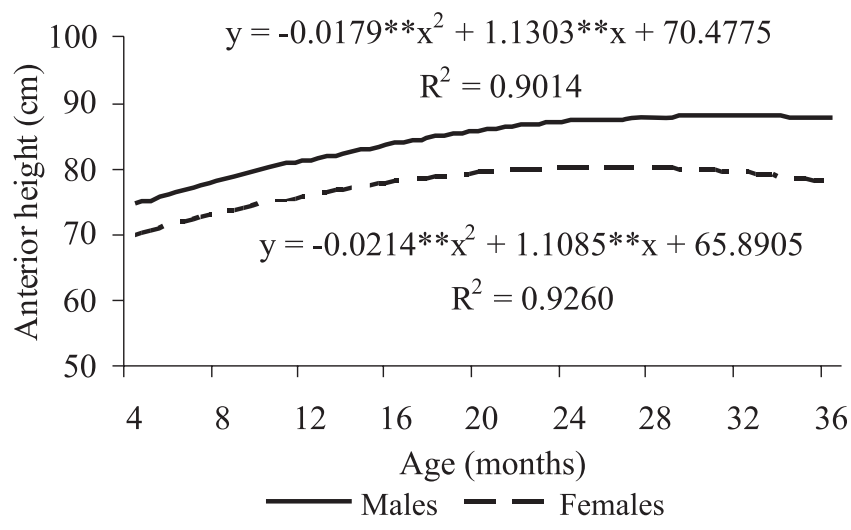

Figure 5 - Anterior height of Santa Ines sheep with ages between four and 36 months; $* *$ significant at $1 \%$ probability $(\mathrm{P}<0.01)$. 


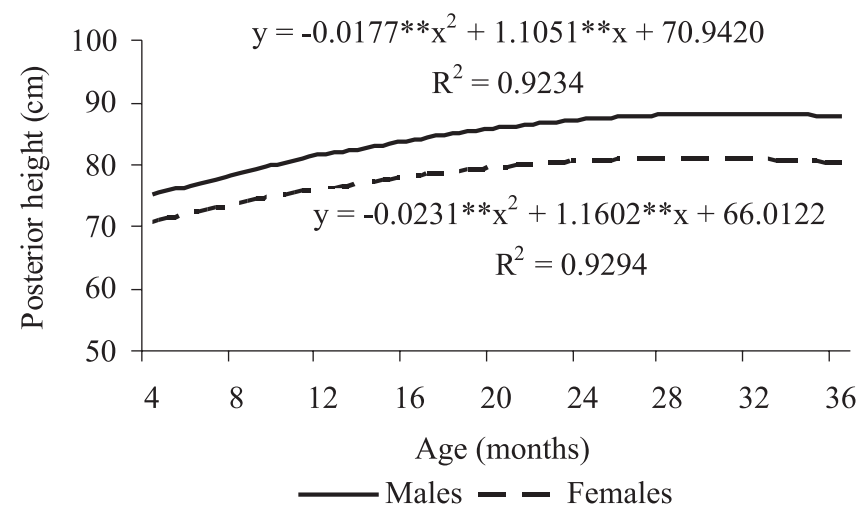

Figure 6 - Posterior height of Santa Ines sheep with ages between four and 36 months; ** significant at $1 \%$ probability $(\mathrm{P}<0.01)$.

$42.7 \%, 49.8 \%$ and $65.5 \%$, respectively, of all the increase observed from four to 36 months of age. While on females these values were $5.5 \mathrm{~cm}, 7.4 \mathrm{~cm}$ and $8.5 \mathrm{~cm}$, corresponding to $44.9 \%, 59.6 \%$ and $68.6 \%$ in the same order.

Similarly to what was observed in the present study, Musa et al. (2006), working with West Africa sheep, observed high increase of anterior height in both sexes up to 12 months of age. At this age, the values found for males and females, $77.1 \mathrm{~cm}$ and $75.4 \mathrm{~cm}$, corresponded to $86.0 \%$ and $90.3 \%$ of anterior height of animals aged $32-36$ months, respectively. In the present study, Santa Ines sheep (male and female) at the age of 8-11 months reached more than $90 \%$ of anterior height of animals of $32-36$ months of age.

Regarding posterior height, it was found that males were superior to females in all ages (Figure 6). This superiority was most evident with advancing of age, when it reached $6.9 \mathrm{~cm}(8.9 \%)$. These results are consistent with the findings of Costa Jr. et al. (2006), who, also working with Santa Ines sheep, observed that males had greater posterior height than females in all categories evaluated, with values ranging from $3.1 \mathrm{~cm}(4.2 \%)$ in young animals to $7.7 \mathrm{~cm}(9.2 \%)$ in adults.

The increase in posterior height occurred more significantly in the age from four to 15 months, and this trait stabilized the growth at 31.2 and 25.1 months in males and females, which presented $88.19 \mathrm{~cm}$ and $80.57 \mathrm{~cm}$, respectively (Figure 6).

Posterior height values obtained for males aged 4-7, $12-15$ and $20-23$ months amounted to $83.0 \%, 94.2 \%$ and $95.2 \%$ of posterior at 36 months aged, respectively. For females, posterior height values found in the same age group amounted to $84.3 \%, 94.0 \%$ and $96.6 \%$ of posterior height at 36 months of age, respectively.
Increases in posterior height observed for males between the first age range (4-7 months) and the ranges of 8-11, $12-15$ and $16-19$ were $6.3 \mathrm{~cm}, 9.9 \mathrm{~cm}$ and $10.0 \mathrm{~cm}$, corresponding to $41.8 \%, 65.8 \%$ and $66.5 \%$, respectively, of all increase from four to 36 months of age. Yet, for females these values were $5.6 \mathrm{~cm}, 7.9 \mathrm{~cm}$ and $8.6 \mathrm{~cm}$, corresponding to $43.6 \%, 61.6 \%$ and $66.7 \%$, in the same order.

Similarly to what was observed in the present study, Afolayan et al. (2006), evaluating Yankasa sheep, found that posterior height, in both sexes, underwent a high increase up to 18 months of age. At this age posterior height found for males and females, $62.8 \mathrm{~cm}$ and $62.6 \mathrm{~cm}$, corresponded to $95.0 \%$ and $95.2 \%$ of posterior height of animals aged 32-36 months, respectively. In the present study, Santa Ines sheep (male and female) reached more than $90 \%$ of posterior height of animals aged $32-36$ months, at the age of 8-11 months.

\section{Conclusions}

Santa Ines sheep shows different growth rates for body measurements, with posterior height being the one that stabilizes earliest and thoracic circumference as that which keeps growing logest. On the other hand, stabilization of body weight and body measurements occurs earlier in females and sexual dimorphism becomes evident with advancing age.

\section{References}

AFOLAYAN, R.A.; ADEYINKA, I.A.; LAKPINI, C.A.M. The estimation of live weight from body measurements in Yankasa sheep. Czech Journal Animal Science, v.51, n.8, p.343-348, 2006.

ARAÚJO, A.M.; VASCONCELOS, I.M.A.; SILVA, F.L.R. Medidas corporais de ovinos deslanados Santa Inês como indicadores do peso vivo. Ciência Animal, v.6, n.1, p-64-68, 1996.

ARAÚJO FILHO, J.T.; COSTA, R.G.; FRAGA, A.B. et al. Efeito de dieta e genótipo sobre medidas morfométricas e não constituintes da carcaça de cordeiros deslanados terminados em confinamento. Revista Brasileira de Saúde Produção Animal, v. 8, n.4, p.394-404, 2007.

COSTA JÚNIOR, G.S.; CAMPELO, J.E.G.; AZEVÊDO, D.M.M.R. et al. Caracterização morfométrica de ovinos da raça Santa Inês criados nas microrregiões de Teresina e Campo Maior, Piauí. Revista Brasileira de Zootecnia, v.35, n.6, p.2260-2267, 2006.

DIXIT, S.P.; GAUR, G.K.; YADAV, D.K. et al. Characterization of the Rampur Bushair sheep in the north temperate region of India. Animal Genetic Resources Information, n.36, p.47-52, 2005. FURUSHO-GARCIA, I.F.; PEREZ, J.R.O.; BONAGURIO, S. et al. Desempenho de cordeiros Santa Ines puros e cruzas Santa Inês com Texel, Ile de France e Bergamácia. Revista Brasileira de Zootecnia, v.33, n.6, p.1591-1603, 2004.

LANDIM, A.V.; MARIANTE, A.S.; MCMANUS, C. et al. Características quantitativas da carcaça, medidas morfométricas e suas correlações em diferentes genótipos de ovinos. Ciência Animal Brasileira, v.8, n.4, p.665-676, 2007. 
MEHTA, S.C.; VIJ, P.K.; JOSHI, B.K. et al. Characterization and conservation of the Malpura sheep breed. Animal Genetic Resources Information, v.16, p.83-91, 1995.

MUSA, H.H.; EL AMIN, F.M.; SULEIMAN, A.H. et al. Body measurements of west African Sheep in Sudan. Journal of Animal and Veterinary Advances, v.5, n.4, p.298-300, 2006.

PEREIRA, L.P.; RESTLE, J.; BRONDANI, I.L. et al. Desenvolvimento ponderal de bovinos de corte de diferentes grupos genéticos de Charolês x Nelore inteiros ou castrados aos oito meses. Ciência Rural, v.30, n.6, p.1033-1039, 2000.

QUESADA, M.; McMANUS, C.; COUTO, F.A.D. Efeitos genéticos e fenotípicos sobre características de produção e reprodução de ovinos deslanados no Distrito Federal. Revista Brasileira de Zootecnia, v.31, n.1, p.342-349, 2002 (supl.).

ROCHA, E.D.; ANDRADE, V.J.; EUCLIDES FILHO, K. et al. Tamanho de vacas Nelore adultas e seus efeitos no sistema de produção de gado de corte. Arquivo Brasileiro de Medicina Veterinária e Zootecnia, v.55, n.4, p.474-479, 2003.

SARMENTO, J.L.R.; REGAZZI, A.J.; SOUSA, W.H. et al. Estudo da curva de crescimento de ovinos Santa Inês. Revista Brasileira de Zootecnia, v.35, n.2, p.435-442, 2006.
SAHANA, G.; JAIN, A.; MAITY, S.B. Characterization and evaluation of Jalauni sheep. Animal Genetic Resources Information, v.34, p.67-73, 2004.

SEARLE, T.W.; GRAHAM, M.C.; DONNELLY, J.B. Change of skeletal dimensions during growth in sheep: the effect of nutrition. Journal of Agricultural Science, v.112, n.3, p.321-327, 1989.

SOUSA, W.H.; LÔBO, R.N.; MORAIS, O.R. Ovinos Santa Inês: Estado de arte e perspectivas. In: SIMPÓSIO INTERNACIONAL SOBRE CAPRINOS E OVINOS DE CORTE, 2., 2003, João Pessoa. Anais ... João Pessoa, 2003. p.510-522.

SOUSA, W.H.; MORAIS, O.R. Programa de melhoramento genético para ovinos deslanados do Brasil: ovinos da raça Santa Inês. In: SINCORTE, 1., 2000, João Pessoa. Anais... João Pessoa: Empresa Estadual de Pesquisa Agropecuária da Paraíba, 2000. p.223-229.

ZUNDT, M.; MACEDO, F.A.F.; ASTOLPHI, J.L.L. et al. Desempenho e características de carcaça de cordeiros Santa Inês confinados, filhos de ovelhas submetidas à suplementação alimentar durante a gestação. Revista Brasileira de Zootecnia, v.35, n.3, p.928-935, 2006. 